\title{
医療機器の審査・安全に関わる学会の役割, 臨床研究の立場から
}

Roles of the academic society about the examination and the safety of medical equipment from the aspect of clinical research

\section{○伊関 洋 ${ }^{1}$, 村垣善浩 ${ }^{1}$, 丸山隆志 ${ }^{1}$, 中村亮一 ${ }^{1}$, 鈴木孝司 ${ }^{1}$, 生田聡子 ${ }^{1}$, 佐久間一郎 ${ }^{2}$}

1. 東京女子医科大学 先端生命医科学研究所 2. 東京大学大学院工学系研究科

OHiroshi Iseki ${ }^{1}$, Yoshihiro Muragaki ${ }^{1}$, Takashi Maruyama ${ }^{1}$, Ryoichi Nakamura'. Takashi Suzuki ${ }^{1}$, Soko Ikuta ${ }^{1}$ and Ichiro Sakuma ${ }^{2}$

1. Institute of advanced Biomedical Engineering \& Science, Tokyo Women's Medical University

2. School of Engineering The University of Tokyo

\section{1. はじめに}

医師が最新の医療機器を使って,より良い治療結果を挙 げようとするモチベーションを向上させる仕組みやインセン チブが必須である.特に, 開発中にどんどん進歩するのが機器 の特徵であり，機器の進歩と医師の技量向上を見越した柔軟 な薬事制度が必要である. 研究・開発・審査（行政，業界，学 会）が同じ土俵で議論 (レギュラトリーコミュニケーション) できるようにする医療機器のレギュラトリーサイエンスの確 立が急務である.

\section{2. 医療機器開発の阻害要因}

国内医療機器メーカーは様々な分野で治療機器の開発を行 ってきたが，上市までの期間が予測不能であること，不具合 発生時の社会的制裁が厳しく医療機器の問題が本体主要産業 へ影響する恐れがあり，そのような様々なリスクを回避する 傾向から，基礎研究は行うが臨床となるとしり込みをすると いう研究開発と実用化の乘離が起こっている. その上, 新薬事 法により医療機器メーカーが提供する試作機を用いた臨床研 究が事実上できなくなり, 新規医療機器の臨床研究・治験の 停滞が現実化した. 現在の医療機器開発の停滞は, リスクマネ ージメントの視点でとらえる必要がある. 環境要因, システム 要因, 組織要因, ルール, コミュニケーションの問題等, 当 事者を取り巻くすべての要因を分析することが必須である. 問題点の抽出 $\rightarrow$ プロアイリング $\rightarrow$ 対策案検討 $\rightarrow$ 対策実施 $\rightarrow$ 効果の確認をすることが重要である. 当事者を責めるのでは なく，人間を取巻くシステムや環境，ルール，情報伝達，機 器, 組織・管理, 体制に目を向け, 改善を進めるのが筋であ る. 本邦では, 定量的な安全では無くて, 定性的な安心を追及 し, 往々にして個人の責任にする傾向がある.既に, 医療機器 開発の問題点は明らかにされており，今必要なのは対策を直 ちに実行することに尽きる.あれこれと詮索する時間は, 残さ れていない.

\section{3. 薬用と医療機器の䢖い}

医療機器を実際に使用するかどうかは医師の判断であり, 一 且使用し始めても医療機器が必要でなくなった場合や, 使用が 適切でないと医師が判断した場合には, 医療機器の使用を単に 中止すれば問題は発生しない.このことは一旦投与したら回収が 難しい薬剂と異なる.これは多くの医療機器の特徵である.

\section{4. 多種多様な機能があるのが医療機器}

1.メス・鋏や聴診器のように完全に医師の責任で使用されるも の.2.通常の薬剤のように医療機器の責任で機能が実現されるも の (たとえば埋め込み型人工臟器).3.医師が積極的に責任を負う のか, 医療機器が積極的に責任を負うのかについてさまざまな組 み合わせが存在するここれを, 薬のように一度投与したら回収で きない仕組みである視点で一律に評価することは合理的では無 い.

5. 医療機器の性格による洀査条件の調整の必要性
医療機器の責任が最も高い,つまり自動で働く場合には, 薬剤 と同様に医療機器の効果や安全性を統計学を含めて証明する必 要がある.ほとんど医師の責任によって使用されるものは, 素材や 構造等に欠陥がなければこれまでの医療機器として承認される べきである.この中間, 医師が消極的責任を負い, 医療機器が積 極的に慣用する部分は, 統計学的な有効性まで求めるのではな く, 安全で有効であることが医師によって示されれば良いのでは ないかと考えられる.

\section{6. おわりに}

医療機器の医師主導治験が, 未だ1件も実施されていない環 境の中で, 高度医療制度の導入により薬事承認前の医療機器の 臨床研究が可能となった.この制度の導入により, 臨床で探索的 に使用して改良するというサイクルを繰り返すことで技術の洗練を 図ることが可能になる. しかし, 医師主導治験を実施するのと同程 度の環境整備 (安全性管理・プロトコル管理・データマネージメン 卜)が必須でありながら, 補償制度・賠償制度の点に関しては, 未 だ不備であり, 早急な整備が急務であると同時に, 整備された臨 床研究環境での実施が求められる.レギュラトリーサイエンスに基 づいた多種多様な医療機器の評価手法の整備が課題である.こ の評価手法の確立については, 産官学の連携で学会が主体的 に取り組むべきである.審査と開発に必要なレギュラトリーコミュニ ユケーションやレギュラトリージャッジメントができる人材育成にも 学会は多大な関与をする必要がある.行政的にも, 医療機器・技 術の適正な経済価值の評価手法とこれを医療保険制度に反映さ せる客観的な指標開発が求められる.

\section{7. 在文献}

1. 菊地 眞, 斉藤清人, 伊関 洋, 橋爪 誠, 吉田 純, 横川 信幸, 山本悦治, 藤本克彦, 高山修一, 三澤 裕, 片倉健男, 稲 見雅晴, 石黒克典, 市川祝善, 野田義寛, 山本芳子: 医療技術 産業戦略コンソーシアム(METIS) 第6回 医療テクノロジー推進 会議 METIS 共通課題検討委員会答申（2007.3.27）

\section{METIS 医療テクノロジー推進会議}

http://www.jfmda.gr.jp/metis/002/002_02.html

3. 共通課題検討委員会答申

http://www.jfmda.gr.jp/metis/002/06_pdf/06-5.pdf

4. 社団法人日本医師会 治験促進センター 医師主導治験

http://www.azskiob.org/doctor_ict/index.html

5. 臨床試験の ABC. 日本医師会雑誌.監修 高久史麿.編集 岩砂和雄, 矢崎義雄, 西岡 清, 橋本信也, 飯沼雅朗, 伊藤澄信. 2006 ; vol.135 臨時増刊号

6. 医療機器に関する経済社会ガイドライン検討委員会報告書 $(2008$ 年 3 月, 経済産業省商務情報政策局医療・福祉機器産業 室)

http://www.meti.go.jp/committee/summary/0004468/report 01.html

7. 高度医療評価制度

http://www.mhlw.go.jp/topics/2008/04/tp0402-1.html 